\title{
Trend-Setters in Environmental Policy: the Character and Role of Pioneer Countries
}

\author{
Martin Jänicke ${ }^{1 *}$ \\ ${ }^{1}$ Free University Berlin, Department of Political and Social Science, Environmental Policy \\ Research Centre, Germany
}

\begin{abstract}
There is reason to believe that environmental policy convergence resulting from policy diffusion is influenced not only by functional imperatives of the world market, but also by a collective behaviour of national governments, where pioneer countries function as (intellectual) leaders under conditions of uncertainty. Their solutions for general environmental problems are adopted by other countries. As a rule, there is one single solution that is preferred by a large group or the majority of countries. This regulatory 'conformism' makes pioneer roles of countries highly relevant. The article analyses the character and role of such 'trend-setters' in environmental policy.

A necessary condition for becoming a pioneer country in environmental policy is a high domestic capacity for environmental policy-making. This encompasses institutional, economic and informational framework conditions as well as the relative strength of the green advocacy coalition of a country. While these factors refer to relatively stable factors of policy-making, this does not explain why sometimes countries give up their roles as pioneers. To explain this, an analytical framework is proposed that encompasses situative factors, strategic factors and actor constellations, especially the coalition between organized proponents of environmental objectives and economic modernizers. This coalition of ecological modernizers may break down, for example in times of economic crisis. The political and economic framework conditions of globalization may sometimes bear impediments for pioneers, but at the same time they also provide incentives for highly advanced countries to take over national pioneer roles - at least in the field of environmental protection, which has become an important issue in the competition for innovation. Copyright (c) 2005 John Wiley \& Sons, Ltd and ERP Environment.
\end{abstract}

Received 28 September 2004; reviesed 18 January 2005; accepted 24 January 2005

Keywords: environmental policy; convergence; pioneer; countries

* Correspondence to: Professor Martin Jänicke, Free University Berlin, Department of Political and Social Science, Environmental Policy Research Centre; Ihnestrasse 22, 14195 Berlin, Germany. E-mail: hauptman@zedal.juberlin.de 


\section{Introduction}

INCE THE EARLY DAYS OF ENVIRONMENTAL POLICY IN THE I97OS, THERE HAVE BEEN PIONEER countries setting regulatory trends in the new policy field. National pioneers have been initiating environmental policy innovations such as new institutions, instruments or modes of operation (Volkery and Jacob, 2003). Their solution for a special environmental problem has been adopted by a relevant group or the majority of other countries, thereby creating a certain policy convergence. Early on, this mechanism was identified as a 'condition for success' in international environmental policy. Moreover, it is no new insight that 'horizontal diffusion' of environmental policy innovations is not less important than 'vertical' regulation by international organizations (Jänicke, I990; see also Busch and Jörgens in this issue; Tews in this issue). The development of global environmental policy and its preferred policy patterns may have been influenced more than most other policies by horizontal 'lesson drawing' (Rose, I993; Jänicke and Weidner, I997). Environmental policy convergence occurs if a large group of countries collectively or individually - but not necessarily simultaneously chooses to adopt a particular policy innovation, which is perceived to be the best (or at least the most frequently adopted) solution for the respective environmental problem.

Pioneer countries are more than 'first movers'. To initiate a regulatory trend, they need a certain 'visibility' and it is important whether or not their policy innovation contributes to the international policy agenda. Here, international institutions play an important role. Pioneer countries are actors within the international policy arena. However, policy innovations as well as their early adoption by other countries primarily depend on domestic factors. First of all, countries need (I) a certain capacity. The concept of political capacity is rather complex. The OECD defines environmental policy capacity very broadly as 'a society's ability to identify and solve environmental problems' (OECD, I994, p. 8). A precise operationalization may be difficult, but it can at least be defined negatively by the relatively stable limits beyond which successful action is impossible. These limits depend on (га) the existing strength of the 'green' advocacy coalition (Sabatier, I999) together with (Ib) the existing institutional, economic or informational opportunity structure, which the proponents of a special policy cannot transcend (e.g. lack of institutions, economic/fiscal resources, or knowledge). Capacities can be enlarged by policies - again within given limits (capacity of capacity-building). An increasingly relevant option of capacity-building is the institutionalized international cooperation. Pioneer activities are also (2) issue specific. Countries may be generally 'strong' in the field of environmental policy, but particular issue areas may have their own stories of success or failure. A pioneer country can be a laggard in certain fields (Germany, for example, is a forerunner regarding energy efficient cars, but it has no general speed limit on highways). There are also (3) situative factors (policy windows) that support or restrict the full use - or the enlargement - of a given capacity. These are necessary to explain why pioneers in environmental policy come and go. There seems to be a wide range of options for highly developed countries either to be a policy innovator or to be more hesitant. The sufficient explanation of a given effective pioneer role is (4) a question of strategic factors: the 'will and skill' (Shonfield) of using a given capacity and situative context.

Pioneer countries in environmental policy, then, are countries where a strong green advocacy coalition is skilful enough to use an advanced opportunity structure - together with situative chances - in order to introduce more than one environmental policy innovation contributing to international regulatory trends. The factors that determine a country's role as a pioneer in environmental policy can be depicted as in Figure I.

The following text will focus on common characteristics of pioneer countries in environmental policy, which have initiated - whether intentionally or not - regulatory trends and processes of policy diffu- 


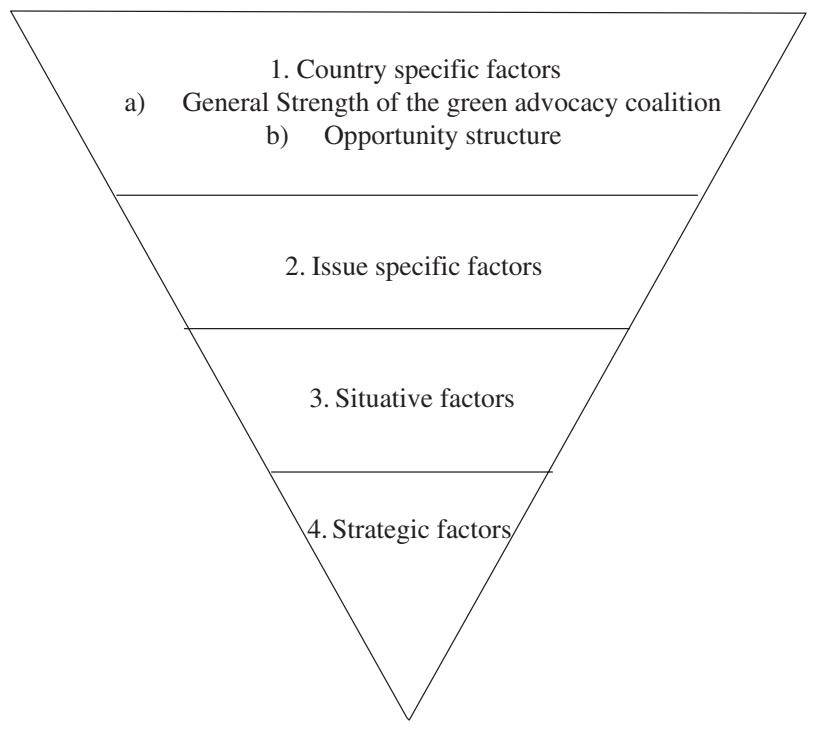

Figure 1. National Pioneer Roles in Environmental Policy: The Funnel of Causality

$\operatorname{sion}^{\mathrm{I}}$ within a larger group of countries. Pioneer countries will be described on the basis of own empirical research as well as a review of the relevant literature. The focus is on the necessary and basic countryspecific elements of the capacity for innovation in environmental policy and the situative factors that create the sufficient conditions for pioneer roles.

However, to start with, I will have a look at the global context: the first question to be answered is whether pioneer behaviour - at least of highly developed countries - is possible in times of economic and political globalization and whether trend-setters in environmental regulation are either restricted by or profit from regulative competition in the international system. As we will see, the international system provides not only negative but also positive incentives for being a leading country in environmental policy.

\section{Pioneers in National Environmental Policy in Times of Globalization}

There are two main challenges to the role of nation states, which seem to compromise the possibility of national pioneer roles in the global context:

- political globalization - the globalization of policies and especially of environmental policy, reducing the role of the sovereign nation state - and

- economic globalization - the role of international markets and multinational corporations, putting pressure on the nation state.

${ }^{\mathrm{I}}$ For an empirical and a theoretic account of the diffusion of environmental policy innovations see the contributions by Busch and Jörgens and by Tews in this issue. 


\section{Pioneer Countries and the Globalization of Policies}

Without any doubt, national sovereignty has been reduced in the context of global governance. A great variety of international regimes were developed in the past that have come to restrict national policymaking, in particular in the field of trade policies. Restrictions to national environmental policy-making are imposed by WTO regulations, EU internal market regulations or the present role of the US in the global environmental policy arena. However, does this also lead to a general withering away of the nation state in environmental policy? Or has the loss of sovereignty been compensated by a new potential of collective action of governments, initiated by policy innovators? Is environmental policy different from other policies that indeed have come under high pressure in the context of globalization?

So far, the fear of a general weakening of the nation state has not been confirmed by empirical research. This is no new finding. However, the long debate has taught us a lot.

Regarding the role of national governments in global environmental governance, we would like to present some theses, which are based on different empirical studies.

Globalization has created a policy arena for pioneer countries, at least in the field of environmental policy.

Economic competition needs markets - political competition needs policy arenas. The political globalization has created such a policy arena, where pioneer roles of countries are relevant. International institutions such as the OECD or the UNEP, but also global networks of all kinds, provide a basis for benchmarking and competition in global environmental policy. This competition for innovation can give even smaller countries a strong position. The influence of small innovative countries (e.g. The Netherlands, Sweden, Denmark) in global policy-making has never before been as important as today in the field of environmental policy (Andersen and Liefferink, I997; Jänicke and Weidner, I997; Jänicke and Jacob, 2002; Andersson and Mol, 2002). It is especially important in the development of global environmental governance as observed in Rio de Janeiro (I992) and Johannesburg (2002). The hard core of national pioneer roles is regulatory competition, often giving support to domestic innovative industries or protecting the national regulatory culture against pressures to adapt to policy innovation from abroad. The present regulatory competition regarding fuel-efficient products sometimes comes near to 'green protectionism' if we take the 'Top Runner Programme' of the Japanese METI as a far reaching example.

In the context of multi-level environmental governance, the (developed) nation state assumes a central role for policy innovation and diffusion.

The national government is both the subject and object of global environmental policy learning and lesson-drawing (Rose, I993; Bennett, I99I; Kern et al., 200I; Tews et al., 2003). Compared with actors at other policy levels national governments are relatively strong players acting under the highest pressure for innovation in relevant problem areas. Their capacity may be altogether insufficient, but it is comparably high as regards financial resources, manpower, professional competence or coercive power. As a rule, the national government is also the most complex nexus of relationships, being part of highly differentiated global and domestic expert networks. The manpower is significantly higher than e.g. that of the secretariats of international regimes (US-EPA: I8 ooo employees versus some hundred in international organizations). National innovation systems and the national lead markets play an important role in the process of global ecological modernization. Generally, the nation state also has the highest visibility; it is the 'first address' in the case of larger problems. There is also no comparable public pressure on political actors in Brussels or on actors at the global level. National elections in Europe are per- 
ceived to be more important than elections at any other level, including elections to the European Parliament. It is therefore the interplay of (relatively) high capacity and high pressure that turns national governments into the most important actors in the process of environmental policy innovation and its subsequent diffusion.

Policies are differently affected by globalization.

The international pressure on wages, taxes on mobile sources and social security provisions is a reality in times of globalization (Scharpf, I999), but environmental as well as health or security standards have their own rules (e.g. WTO) and their own logic in international regulatory competition. It also seems that the conditions for concerted actions of environmental ministers in the global arena are at least not bad, if compared with other policies. Environmental policy has been very competent in using the opportunity structure of multi-level governance.

Environmental policy innovation as well as regression is caused primarily at the national level.

In an expert inquiry on environmental policy-making in 20 countries we asked for the main restrictive sectors in environmental protection. The answer was first the energy sector, second road traffic, third agriculture, fourth the construction sector (Jänicke and Weidner, I997). These are actually sectors that are not under hard global competition, partly even the contrary is true (agriculture, the power industry and the construction industry strongly depend on public or regulated demand). Furthermore, the possibility of countries deliberately choosing the role of being either an innovator or a laggard in environmental protection (e.g. the US, Japan, the UK or, more recently, Denmark) reveals a range of options that contradicts the argument of a general weakening of the nation state (Dryzek et al., 2002; Andresen and Agrawala, 2002; Weidner and Jänicke, 2002).

\section{Pioneer Countries and Economic Globalization}

Even more pessimistic arguments regarding the capacity of the nation state focus on the restrictive role of the global economy. The most popular argument is the 'race-to-the-bottom' (RTB) hypothesis of a regulatory competition between countries deteriorating the position of governments in fields such as environmental policy.

There is no general 'race to the bottom' in environmental policy - but why?

Several empirical cross-national studies have rejected the RTB-hypothesis. This discussion has provided many insights into the role of environmental policy in the competition between national economies. Many arguments against the RTB hypothesis are well known today (Vogel, 200I; Wheeler, 200I; Drezner, 200I): Countries and companies that trade with countries with strict regulations tend to adopt stricter policies themselves (Eliste and Fredricksson, unpublished manuscript) - the most important markets are rather strictly regulated. The globalization of environmental policy has partly changed the framework conditions of the world market (Jänicke and Weidner, I997; Weidner and Jänicke, 2002; Vogel, 200I). Regulatory competition in the field of environmental protection can create first-mover advantages for national economies. This is part of the global competition (Porter and van der Linde, I995; Wallace, I995) and essential to the development of 'environmental lead markets' (Jänicke and Jacob, 2002). Multinationals tend to use the same standards everywhere (Wheeler, 200I). Differences in environmental standards tend to decrease; generally they are less important than differences e.g. in 
labour costs or taxes. In the EU, harmonized standards offer a strong coercive 'floor' below which no member state can move. So far, this forced convergence has taken place at comparably high levels of protection.

Furthermore, the environmental issue has, to a certain degree, become a dimension of general technological progress. 40 per cent of the innovations in 2010 are expected to be relevant for environmental improvement (Faucheux, 2000).

Strict environmental regulations (within limits) remain a possibility to protect, or support, national industries (Andersen and Liefferink, 1997). The ambitious 'Top Runner Programme' of the Japanese METI, which aims to increase the energy efficiency even of imported products, is an interesting example (Schröder, 2003). The protests by the US government against the expected barriers for imported goods - which by the way were unsuccessful - underline this hypothesis. The Top-Runner approach for cars has even diffused to California (2002) and other US states as well as to China (2004).

Pioneer countries in environmental policy have open and highly competitive economies.

Most of the environmental pioneer countries do not only have especially open, export oriented economies, they are also highly competitive. This clearly contradicts the argument of a restrictive role of the global economy. The Global Competitiveness Report shows a remarkably high correlation $\left(R^{2}=\right.$ o.89) between ambitious environmental policy and the competitiveness of a country (World Economic Forum, 2000). Other studies have revealed a similar relationship (Sturm et al., 2000). Of course, this is no causal proof. The causal relation can go in both directions; third factors (e.g. the GNP per capita) may also be important. However, in the light of such a correlation, nobody can any longer insist on the traditional economic argument of an immanent contradiction between competitiveness and a demanding environmental policy (see also Kok, 2004).

The open ('globalized') national economy needs and is characterized by strong government, both in size and scope.

The idea of a pressure diminishing the role of governments especially in open, globalized national economies has not been supported by empirical research. Cross-national studies have shown that public expenditures in open economies in the OECD tend to be relatively higher (see Cameron, I978; Garrett, I998; Bernauer, 2000). However, it seems plausible to assume both a larger size and a larger scope of government activities in countries that are highly integrated into the international economy (Jänicke and Jacob, 2002; Levi-Faur and Jordana, 2005). Open economies need

- a well developed infrastructure for successful international competition, which means more money and more public activities in fields such as education, R\&D or transport

- the compensation of distributional and other effects of rapid structural changes connected e.g. with a low degree of protection of domestic industries

- more regulatory activities of all kinds necessary to adapt to international developments (e.g. standards).

A strong role in environmental policy, therefore, does not contradict the general role of government in open economies.

New environmental technologies, as a rule, start from national 'lead markets', based on supporting pioneer policies. 
A lead market is the core of the world market, where the local users are early adopters of an innovation on an international scale (Beise, 200I). The US as lead market for the internet, Japan as lead market for fax or Finland as lead market for mobile phones are well known examples. Empirically, lead markets are characterized by e.g. high per capita income, high quality standards and pressures for change. Lead markets for new environmental technologies are characterized by two additional factors. (I) Environmental innovations relate to global (environmental) needs. This means that there is a global market potential. This may help to understand why the environmental issue is not in a hopeless situation in the global economy. (2) Lead markets for environmental innovations are typically not only stimulated by higher environmental preferences of consumers in developed countries. Due to market failure, they also depend on political promotion measures (sometimes also by NGOs), or on political intervention in the market (Jänicke and Jacob, 2002). In other words: in order to exploit the opportunities of global 'green' markets, a pro-active role of national government is typically necessary. National regulations for catalytic converters or desulphurization technology as well as supporting policies for renewable energies are prominent examples.

To summarize the presented theses: globalization, both political and economic, has not only created restrictions to national pioneer behaviour in environmental protection. It has at the same time created strong incentives for national policy innovations in this field. The most important fact seems to be that the environmental issue has come to play an increasing role in the competition for innovation, which is more relevant for developed countries than for others. This corresponds with the above mentioned fact that countries with strict environmental regulations are more competitive than others.

\section{Common Characteristics of Pioneers in Environmental Policy}

Table I presents the counts for the introduction or early adoption of 2I different environmental policy innovations. The ranking of innovation/early adoption may differ with the mix of selected policy innovations, and it is only a ranking on the level of policy outputs, not of implementation or outcome. Authors focusing on policy performance such as Andersen and Liefferink (I997) partly deviate from this list of green pioneers. They would have included Austria ('a latecomer which became a pioneer') or Norway,

\begin{tabular}{lll}
\hline Country & $1970-1985$ & $1985-2000$ \\
\hline Sweden (11) & 7 & 4 \\
USA (11) & 9 & 2 \\
Japan (10) & 8 & 2 \\
Denmark (9) & 5 & 4 \\
Finland (8) & 4 & 4 \\
France (7) & 5 & 2 \\
Germany (7) & 5 & 2 \\
The Netherlands (7) & 3 & 4 \\
UK (6) & 4 & 2 \\
Canada (6) & 2 & 4 \\
& - & - \\
& 52 & 30
\end{tabular}

Table 1. Pioneer countries in environmental policy: policy innovation or early adoption 1970-2000 (introduction of 21 new environmental policy institutions, laws or instruments: innovation plus first three adoptions)

Source: FFU/Busch and Jörgens, 2005. 
but not France (see also Scruggs, 2003). This underlines the argument of the active role of small European countries in the last ten to I5 years. What I would like to show is the existence of countries that have repeatedly taken the risk of being environmental pioneers, but also the change of pioneer roles over time. The US and Japan, which together with Sweden became important trendsetters of environmental regulation in the industrialized world throughout the I970s, have taken a quite different position in the I980 and I990s.

Therefore, in explaining pioneer roles of countries, we must differentiate between relatively stable and relatively unstable factors (Andersen and Liefferink, I997; Sabatier, 1999), or between stable structures or capacities and other more variable 'situative' conditions that cause changes within a given capacity (Jänicke and Weidner, 1997).

\section{The Strength of the 'Green' Advocacy Coalition}

Sabatier's concept of advocacy coalition is useful for the explanation of policy innovation. It focuses on the kind of actor motivation (belief system) and the combined strength of different actors in relation to the opposing coalition. This is put in relation to the stable structures and situative factors of action (Sabatier, I999). The approach is actually related to issue-specific policy innovations, but it makes sense to describe the general country-specific driving forces for environmental policy innovations in a similar way. In particular, the coalition aspect can be used for this purpose. The advocacy coalition generally supporting environmentally friendly policy solutions does first consist of actors of environmental administrations or of the ecology movement. The strength and competence of the environmental government divisions as well as the organizational strength and professionalism of the environmental movement are important characteristics of pioneer countries. In the Netherlands, for example, the degree of organization of environmentalists is higher than that of the trade unions (Jänicke and Weidner, I997).

The most important characteristic, however, seems to be a coalition between these traditional proponents of environmental policy and modernizers within industry. Pioneer countries in environmental policy are characterized by a coalition for ecological modernization (Jänicke, I984, 2000). Especially Japan had a strong eco-modernizing coalition in the early I970s, partly substituting a weak environmental movement. There was much environmental optimism within parts of the industry, and in fields such as renewable energy and energy efficiency the MITI was a driving force of ecological modernization. Even some kind of eco-restructuring resulted from this coalition. When the coalition broke down in the I980s, the pioneer role of the country came to an end (it may have been revived in recent years). A similarly cautious environmental optimism within parts of the industry and at least a modernizing coalition with green administrators and NGOs could be observed in most of the countries mentioned in Table I. In the Germany of the early I970s and of recent years, the majority of trade unions were part of this coalition. The strong legal support for renewables in Germany cannot be explained without this kind of coalition. However, the green advocacy coalition as such also depends on situative factors (only the actors are 'stable factors'). So far, green coalitions for ecological modernisation have only been active for a certain length of time and have ceased to exist after a while.

\section{Structural Framework Conditions}

\section{Economic Factors}

The most important characteristic of 'green' pioneer countries is their high degree of economic development (measured by GNP per capita). The level of national income leads not only to a higher availability of technology or fiscal resources. It also strongly corresponds with other factors. The level of education, which is an important condition for the perception of problems and adoption of new knowl- 
edge, is highest in rich countries. Similar parallels have been shown e.g. for the strength of institutions (World Bank, 2003).

In our context, the dominant role of the level of economic development is crucial mainly for two reasons.

Highly developed countries are characterized by higher perceived environmental pressures from energy production, traffic, chemical substances or urban sprawl - being perceived by better educated people. At the same time they have higher administrative, economic and scientific capacities to solve environmental problems - at least those for which technological means are available. The interplay between perceived high environmental pressure and high environmental capacity seems to be the most important mechanism to explain pioneer roles of highly developed countries.

Therefore highly developed countries by function and capacity are the candidates for being environmental pioneers. However, there are differences within this group of countries. This leads to the other characteristics.

\section{Political and Institutional Factors}

The structure of the political system. The openness of the political system for new interests and ideas as well as the capacity for policy integration and coordination seems to be an important institutional framework condition for environmental policy innovations of pioneers (Kitschelt, I983; Jänicke, I990). The factor 'strong government' has already been mentioned above.

The policy style. It is generally agreed that a culture of dialogue and consensus is an important condition for successful environmental policy. This seems especially important for the creation of a broad coalition for ecological modernization. An innovation oriented environmental policy needs networking and communication of all kinds (Jänicke et al., 2000).

The special factor 'EU membership'. Why is it that so many EC/EU member states have successfully initiated environmental policy innovations since I985? An answer may be the revision of the treaty at that time introducing strong regulations for environmental policy. The new regulation created a double institutional advantage for environmental innovations (Héritier et al., I994). The EU must firstly, at least in principle, accept a 'high level of protection' in member states; it must secondly seek to harmonize innovations in environmental policy implemented at nation-state level. Pioneer countries, for their part, often have an interest in anchoring their policy innovations within the EU framework in order to minimize their subsequent need to adapt to European policy. It is also often a matter of 'Europeanizing' certain national pioneer measures favouring the particular country's domestic industry. This underlines the importance of EU harmonized measures. Policy diffusion within the EU, however, takes place not only by way of vertical Europeanization but also horizontally from country to country (see also Knill and Lenschow in this issue). The $\mathrm{CO}_{2}$ tax is an example of such 'horizontal' diffusion.

Cognitive and Informational Factors: the Knowledge Base

Pioneers of environmental policy are characterized by high R\&D expenditures. This may also be seen as an indicator for a strong national innovation system, which plays an important role for technologybased environmental policy approaches. Green pioneer countries tend to define environmental policy and sustainable development in terms of innovation policy and ecological modernization.

However, the knowledge base of policy innovation must not only be produced, it has to be transferred and it has to be adopted by an educated public. All three conditions are necessary. A highly developed research capacity together with an effective system of education may be insufficient, if the transfer by the media is restricted, e.g. by a dominant commercial structure.

The immediate transfer of innovative knowledge to the political elite may be especially important. The pioneer role of Germany in the field of climate protection cannot be explained without the role of a par- 
liamentary 'Enquete-commission' in the late I980s, which created the respective knowledge base for the Parliament and an educated community (the same could be said for the German policy of a phase-out of nuclear energy).

\section{Unstable, Situative Factors: When Pioneers Give Up}

We now turn from the relatively stable factors of environmental pioneer countries to the more unstable (Andersen and Liefferink, I997, p. I8; Jänicke and Weidner, I997, p. 7). The role of situative opportunities and of 'policy windows' has for a long time been regarded as important for policy innovation (Kingdon, I995; Sabatier, I999). Situative - restrictive or supporting - factors can be sudden changes of economic conditions such as recessions, high oil prices or new technologies. Political events or changes such as government turnover, or policy innovations in other countries, can play a similar role. The role of new, sometimes shocking information (from publications such as The Limits to Growth to events such as the Chernobyl accident) has often been mentioned in this context.

The situative factors not only explain the full use of a given capacity to play a pioneer role in environmental policy. Today they are especially important if it comes to explaining a political roll-back, or the under-exploitation of a given capacity. Examples are the US under Reagan and Bush (junior), Japan during the 'bubble' crises after the mid-I980s (Dryzek et al., 2002; Desai, 2002), the UK under Margaret Thatcher or more recently Denmark and The Netherlands after a government turnover. Sweden, on the other hand, experienced a comeback as environmental pioneer in the late I99os under Göran Persson.

We need more comparative research about such policy changes leading to an abandonment of pioneer roles. Again the state of the economy is the most important explanation. However, it also seems plausible that pioneer roles of advanced countries can finally lead to frustration and overextension. Perceived over-regulation or competitive disadvantages - especially in times of crisis - are common to all the cases mentioned. Changes in government have been another factor, but are closely connected with such perceptions. Self-destroying success may be another, paradoxical reason for giving up a pioneer role in environmental policy: clear improvements where problems are most visible (e.g. water, or air pollution) can weaken the support for further ambitious measures. All this may lead to a breakdown of the coalition between proponents of environmental objectives and industrial modernizers. This is the lesson that can be drawn from several former pioneers: the coalition of ecological modernizers is no stable factor.

There are, on the other hand, also limits for a roll-back within highly developed former pioneer countries, and this good news may have to do with both the still existing high environmental capacity of such countries and the mechanisms of competition for innovation that have been described above. The US, for example, is still a strong exporter of environmental technologies. There is also the empirical fact of more than one comeback (UK, Sweden, Japan, Germany), which can be understood as the renewed full use of a given capacity.

\section{Issue-Specific Factors}

Andersen and Liefferink (1997) have differentiated between country-specific factors (which we described) and issue-specific factors of national pioneer behaviour. Pioneer roles are typically limited to those issues for which a country has acquired a competence in the past. A path dependency of environmental policy also arises from the perception from abroad: countries that served as an example in the past are likely to be under closer observation from other countries.

I have not discussed individual issue areas in environmental protection. However, it is clear that issues - the kinds of problem as well as of solution - make a difference. The problem may be highly visible 
or latent (silent deterioration). The polluter may be strong or weak. The most important factor, however, is the availability (or lack) of a marketable technical solution. I have stressed the point that environmental innovations can profit from the fact that the environmental issue has become an important dimension of the competition for innovation. However, this advantage in times of economic globalization is restricted to technology-based policies.

\section{Strategic Factors}

Whether and how a given environmental capacity and a situative policy window are used depends on strategic factors, on will and skill. There are several options for pioneers: they may be only forerunners, reacting to domestic problems or certain market opportunities; in this case it is the adoption of the policy innovation by other countries - or the EU - that determines the pioneer role. Alternatively, they may act as active 'pushers' (Andersen and Liefferink, I997; Andresen and Agrawala, 2002), transferring their policy innovation to the higher level, e.g. the EU. Sweden, the Netherlands, Denmark, Germany and the UK have combined both strategies several times. Germany has promoted the introduction of renewable energies by organizing the international conference Renewables 2004.

\section{Setting the Trend}

As mentioned above, pioneers in environmental policy are more than first movers. I have characterized them in addition not only by the plurality of environmental policy innovations, but also by the international 'visibility' of the country. The reputation of the pioneer country within the international community is another important factor. Reputation or intellectual leadership is different from power-based leadership (Andresen and Agrawala, 2002) and the reputation of being a policy innovator may have a special attractiveness for smaller countries.

National regulations do influence international markets and the global economy needs at least some harmonization. Policy convergence and regulatory trends therefore have a strong basis. The harmonization of national regulations often comes from international agreements. However, the evolution of regulatory trends seems to a large degree to be an independent process. Here also the design of the policy innovation is important. In order to fit an international regulatory trend, the environmental policy innovation must fulfil certain conditions. In a study on environmental lead markets and their supporting policies we found the following factors to be of particular importance (Jacob et al., 2005): The environmental innovation must be transferable and useful for other countries. ${ }^{2}$ It should relate to global environmental needs. Another important factor is the close relationship of a national policy innovation to the international policy agenda (e.g. the Kyoto Protocol). It also must have demonstrated to be (at least with high probability) effective and acceptable. This demonstration effect again depends to a certain degree on the visibility of the country. The regulatory trend also depends on its anticipation by adopting countries. Not only proactive enterprises anticipate regulations (Jacob, I999). Countries too - and especially export-oriented economies - tend to orient themselves towards future regulatory developments. If there are competing policy designs for a certain environmental problem, the adopters tend to be cautious as long as the prognosis about the finally converging policy design is insecure (Busch and Jörgens, 2005 and in this issue). Its should also be underlined that each policy adoption has its own national history of success if there is no international agreement, the adoption depending not only on policy capacities and on general environmental conditions of a country but also on situative factors such as catastrophic

\footnotetext{
${ }^{2}$ The importance of the specific attributes of a policy innovation for its propensity to diffuse to other countries is stressed by Tews in this issue
} (see also Kern et al., 200I; Tews et al., 2003). 
events, government changes, technical developments or sudden changes of energy prices. The main message from the lead market research is that the transfer activity of the pioneer country plays a minor role compared with this internal logic of adoption.

\section{Conclusions}

We have seen that environmental policy diffusion and convergence are not only influenced by functional imperatives of the world market, but also by a collective behaviour of national governments, where a limited number of pioneer countries function as (intellectual) leaders by demonstrating the political and economic feasibility of certain solution and thereby legitimating subsequent adoptions of the same policy innovation in other countries. Policy convergence results from the fact that, as rule, it is one single solution that is preferred by a large group or the majority of countries. Pioneers further the spread or uptake of advanced environmental policy concepts. The process of adoption - having its own logic - seems to be characterized by a certain regulatory conformism. From this perspective, policy convergence seems to result not least from a 'group behaviour' of national governments, where pioneer countries play the (intellectual) leadership role under conditions of uncertainty.

A necessary condition for becoming a pioneer is a high capacity for environmental policy-making. This encompasses the institutional, economic and informational opportunities and the relative strengths of the green advocacy coalition of a country. While these factors refer to relatively stable factors of policymaking, this does not explain why pioneer roles are sometimes given up. Additional determinants have to be taken into consideration to explain the ups and downs in environmental policy. To explain this, the article has proposed an analytical framework that also encompasses situative factors, strategic factors and actor constellations, especially the coalition between organized proponents of environmental objectives and economic modernizers. This coalition of ecological modernizers may break down in times of economic crisis, or as an effect of overstraining the existing consensus or even as a paradox effect of visible improvements of the environment. However, the existing capacity of a country - together with certain incentives of the international system - will prevent an excessive roll-back and provide chances for a 'comeback' (as in the cases of Sweden and Britain).

The political and economic framework conditions of globalization may sometimes bear impediments for pioneers, but at the same time they also provide incentives for certain advanced countries to take over national pioneer roles - at least in the field of environmental policy. The existing opportunities, however, seem to be restricted to technology-based solutions, and so far they are restricted to highly developed OECD countries - often EU member states - with a strong position in the competition for innovation. Whether pioneering strategies become viable for developing countries as well should be, however, the subject of further investigation.

\section{Acknowledgements}

I would like to thank Klaus Jacob and one anonymous reviewer for their valuable comments.

\section{References}

Andersen MS, Liefferink D. I997. European Environmental Policy. The Pioneers. Manchester University Press: Manchester. Andersson M, Mol APJ. 2002. The Netherlands in the UNFCCC process - leadership between ambition and reality. International Environmental Agreements: Politics, Law and Economics 2: 49-68. 
Andresen S, Agrawala S. 2002. Leaders, pushers and laggards in the making of the climate regime. Global Environmental Change I2: $4 \mathrm{I}-5 \mathrm{I}$.

Beise M. 200I. Lead Markets. Country Specific Success Factors of the Global Diffusion of Innovations. Physica: Heidelberg.

Bennett CJ. I99I. What is policy convergence and what causes it? British Journal of Political Science 2I(2): 2I5-233.

Bernauer Th. 2000. Staaten im Weltmarkt: Zur Handlungsfähigkeit von Staaten trotz wirtschaftlicher Globalisierung. Leske and Budrich: Opladen.

Busch P-O, Jörgens H. 2005. Globale Diffusionsmuster umweltpolitischer Innovationen. Environmental Policy Research Centre: Berlin.

Cameron DR. 1978. The expansion of the public economy: a comparative analysis. American Political Science Review 72(4).

Desai U (ed.). 2002. Environmental Politics and Policy in Industrialized Countries. MIT Press: Cambridge, MA.

Drezner DW. 200I. Globalization and policy convergence. International Studies Review 3(I): 53-78.

Dryzek JS, Hunold Ch, Schlosberg D et al. 2002. Environmental transformation of the state: the USA, Norway, Germany and the UK. Political Studies 50: 659-682.

Faucheux S. 2000. Environmental policy and technological change; towards deliberative governance. In Innovation-Oriented Environmental Regulation: Theoretical Approaches and Empirical Analysis, Hemmelskamp J, Rennings K, Leone F (eds). Physica: Heidelberg; I53-I7I.

Garrett G. I998. Partisan Politics in the Global Economy. Cambridge University Press: Cambridge.

Harvard University, World Economic Forum. 2000. The Global Competitiveness Report 2000. Oxford University Press: New York.

Hemmelskamp J, Rennings K, Leone F (eds). 2000. Innovation-Oriented Environmental Regulation. Theoretical Approaches and Empirical Analysis, ZEW Economic Studies io. Physica: Heidelberg.

Héritier A, Mingers S, Knill C, Becka M. I994. Die Veränderung von Staatlichkeit in Europa - Ein regulativer Wettbewerb: Deutschland, Großbritannien, Frankreich. Leske and Budrich: Opladen.

Jacob K. I999. Innovationsorientierte Chemikalienpolitik. Politische, soziale und ökonomische Faktoren des verminderten Gebrauchs gefährlicher Stoffe. Herbert Utz: München.

Jacob K, Beise M, Blazecjzak J, Edler D, Haum RK, Jänicke M, Löw Th, Rennings K, Petschow U. 2005. Lead Markets for Environmental Innovations. ZEW: Berlin.

Jänicke M. I984. Umweltpolitische Prävention als ökologische Modernisierung und Strukturwandel, IIUG Discussion Paper 84-I, Wissenschaftszentrum Berlin.

Jänicke M. I990. Conditions for environmental policy success: an international comparison. The Environmentalist I2(I): 47-58.

Jänicke M. 2000. Ecological Modernization. Innovation and Diffusion of Policy and Technology, FFU Report o0-08. Forschungsstelle für Umweltpolitik-Freie Universität Berlin: Berlin.

Jänicke M, Blazecjzak J et al. 2000. Environmental policy and innovation: an international comparison of policy frameworks and innovation effects. In Innovation-Oriented Environmental Regulation. Theoretical Approaches and Empirical Analysis, Hemmelskamp J, Rennings K, Leone F (eds). Physica: Heidelberg; I25-I52.

Jänicke M, Jacob K. 2002. Ecological Modernisation and the Creation of Lead Markets, FFU Report 02-03, Freie Universität Berlin. 2004. Global Environmental Politics 4(I).

Jänicke M, Weidner H (eds) with Jörgens H. I997. National Environmental Policies: a Comparative Study of Capacity-Building. Springer: Berlin.

Kern K, Jörgens H, Jänicke M. 200I. The Diffusion of Environmental Policy Innovations: a Contribution to the Globalisation of Environmental Policy, Discussion Paper FS II OI-302. Social Science Research Centre: Berlin.

Kingdon JW. 1995. Agendas, Alternatives, and Public Policies, 2nd edn. HarperCollins: New York.

Kitschelt H. 1983. Politik und Energie. Campus: Frankfurt/M.

Kok W. 2004. Facing the Challenge. The Lisbon Strategy for Growth and Employment, report from the High Level Group chaired by Wim Kok. European Communities: Luxembourg.

Levi-Faur D, Jordaua J (eds). 2005. The Rise of Regulatory Capitalism: The Global Diffusion of a New Order. The Annals of the American Academy of Political and Social Science. Vol. 598, March 2005.

Liefferink D, Andersen MS. 1996. The Innovation of EU Environmental Policy. Scandinavian University Press: Oslo.

Organisation for Economic Cooperation and Development (OECD). 1994. Capacity Development in Environment. OECD: Paris.

Porter ME, van der Linde C. I995. Green and competitive: ending the stalemate. Harvard Business Review September-October: I2O-I34.

Rose R. 1993. Lesson-Drawing in Public Policy: a Guide to Learning Across Time and Space. Chatham House: Chatham, NJ.

Sabatier PA (ed.). I999. Theories of the Policy Process. Westview: Boulder, CO.

Scharpf FW. 1999. Regieren in Europa. Effektiv und demokratisch? Campus: Frankfurt.

Schröder H. 2003. From Dusk to Dawn. Climate Change Policy in Japan, dissertation, Fachbereich Politik- und Sozialwissenschaften der Freien Universität Berlin. 
Scruggs L. 2003. Sustaining Abundance. Environmental Performance in Industrial Democracirs. Cambridge University Press: Cambridge.

Sturm A, Wackernagel M, Müller K. 2000. The Winners and Losers in Global Competition. Why Eco-Efficiency Reinforces Competitiveness: a Study of 44 Nations. Rüegger: Chur.

Tews K, Busch P-O, Jörgens H. 2003. The diffusion of new environmental policy instruments. European Journal of Political Research 42(4).

Vogel D. 200I. Is there a race to the bottom? The impact of globalization on national regulatory policies. The Tocqueville Review/La Revue Tocqueville 22(I).

Volkery A, Jacob K. 2003. Pioneers in Environmental Policy Making. Konferenzbericht, FFU Report 03-04.

Wallace D. 1995. Environmental Policy and Industrial Innovation. Strategies in Europe, the US and Japan. Earthscan: London.

Weidner H, Jänicke M (eds). 2002. Capacity Building in National Environmental Policy. A Comparative Study of 17 Countries. Springer: Berlin.

Wheeler D. 200I. Racing to the bottom? Foreign investment and air pollution in developing countries. Journal of Environment and Development Io(3): 225-245.

World Bank. 2003. World Development Report 2003. Washington, DC.

World Economic Forum (ed): The Global Competitiveness Report, Oxford University Press: NY.

\section{Biography}

Professor Martin Jänicke, Free University Berlin, Department of Political Science, Environmental Policy Research Centre; Ihnestrasse 22, I4I95 Berlin, Germany.

Tel. $+49-30-83855098$

Fax $+49-30-83856685$ 